\title{
A kardiovaszkuláris kockázat csökkentése 1-es típusú diabetes mellitusban, felnőttkorban
}

\author{
Hosszúfalusi Nóra dr., Kempler Miklós dr.
}

\begin{abstract}
Ósszefoglalás
Az elmúlt évtizedekben jelentösen javult - svéd adatok szerint 29\%-kal csökkent - a mortalitás 1-es típusú diabetes mellitusban (TIDM). Ennek ellenére a halálozás még mindig 2-8-szoros az átlagnépesség adataihoz képest: ez 20 éves életkorban körülbelül 12 évvel csökkenti a várható élettartamot. Új megfigyelés, hogy minél hamarabb kezdödik a TiDM, annál nagyobb a halálozási kockázat, függetlenül a betegségtartamtól. A vezetö halálok a kardiovaszkuláris halálozás. A korai, komplex kardiovaszkuláris rizikócsökkentés fontos aspektusa az 1-es típusú cukorbetegek gondozásának. Ennek összetevői a jó glykaemiás állapot a hypoglykaemia lehetö legritkább elöfordulása mellett, egészséges életmód, rendszeres mozgás, az elhizás és a dohányzás elkerülése, valamint az egyéb, gyógyszerrel is befolyásolható rizikótényezök (vérnyomás, LDL-koleszterin, albuminuria) célértékre történö kezelése, esetleg aszpirinterápia primer prevencióként. A szerzök a nemzetközi és hazai ajánlások alapján foglalják össze a kardiovaszkuláris prevenció lehetöségeit 1-es típusú diabetes mellitusban, hangsúlyozva a fiatalkori kockázatcsökkentés fontosságát.

Kulcsszavak: 1-es típusú diabetes mellitus, T1DM, halálozás, kardiovaszkuláris halálozás, kardiovaszkuláris rizikó
\end{abstract}

\section{Cardiovascular risk reduction in type 1 diabetes mellitus in adults}

Summary: In the past decades, the mortality of type 1 diabetes mellitus (TIDM) has greatly improved, according to the Swedish database the mortality decreased with $29 \%$. Still there is 2-8-fold higher mortality rate in T1DM compared to the general population, causing an average of 12-year lower life expectancy in a 20-year-old individual. Recent studies suggest that earlier start of the disease is associated with higher mortality risk regardless of disease duration. The leading cause of death is cardiovascular mortality. Early complex cardiovascular risk reduction is an important aspect of the management of patient with TIDM. Its components are the good glycaemic control at the lowest possible incidence of hypoglycaemia, healthy lifestyle, regular exercise, avoidance of obesity and smoking, as well as treating other medically manageable risk factors (such as blood pressure, LDL-cholesterol and albuminuria) to target values. We summarize the available options of cardiovascular prevention in type 1 diabetes mellitus based on national and international guidelines and emphasize the importance of risk reduction among the young patients with TIDM.

Keywords: type 1 diabetes, T1DM, mortality, cardiovascular mortality, cardiovascular risk

Rövidítések

ABPM: ambuláns vérnyomás-monitor (ambulatory blood pressure monitoring); ACE: angiotenzin-konvertáló enzim (angiotensin-converting-enzyme); AHA: Amerikai Szív Társaság (American Heart Association); ARB: angiotenzin II-receptor blokkoló (angiotensin-II-receptor blocker); CHD: koszorúér-betegség (coronary heart disease); CVD: kardiovaszkuláris betegség (cardiovascular disease); DBP: diasztolés vérnyomásérték (diastolic blood pressure); EDIC: Epidemiology of Diabetes Interventions and Complications; EHS: Európai Hypertonia Társaság (European 
Society of Hypertension); EKG: elektrokardiográf; ESC: Európai Kardiológiai Társaság (European Society of Cardiology); SBP: szisztolés vérnyomásérték (systolic blood pressure)

\section{A halálozás és a kardiovaszkuláris morbiditás alakulása 1-es típusú diabetes mellitusban}

Az elmúlt évtizedekben jelentősen javult a mortalitás 1-es típusú diabetes mellitusban (T1DM). Egy 2013-ban megjelent japán tanulmány szerint a 18 éves életkor előtt kezdődő 1-es típusú cukorbetegség halálozási aránya nagymértékben csökkent: míg ez a szám az 1965-69 között diagnosztizált eseteknél 35 éves követési idő alatt az átlagnépességhez viszonyítva 19,3-szer nagyobb volt, addig az 1975-79 között kezdődő T1DM esetén, 25 éves követési idő alatt az arány 6,6-szeresre csökkent. ${ }^{1}$ A T1DM kezelésében mérföldkőnek számító randomizált klinikai tanulmány, a DCCT (Diabetes Control and Complications Trial, egy multicentrikus, prospektív randomizált klinikai vizsgálat), majd az ezt követő, a DCCT-ben részt vevő betegeket tovább megfigyelő, obszervációs tanulmány, az EDIC (Epidemiology of Diabetes Interventions and Complications Diabetes) azt mutatta, hogy az átlagosan 27 éves követési idő alatt a DCCT/EDIC teljes betegpopulációja (a DCCT során intenzíven és konzervatív módon kezelt betegcsoportok együttvéve) mortalitása nem különbözött az amerikai háttér-népesség halálozási arányától. A $\mathrm{HbA}_{1 c}$-vel jellemzett glykaemás kontroll jelentősen befolyásolta a halálozási arányt. A DCCT alatt intenzív módon kezeltek mortalitása nem szignifikánsan, de kisebb, míg a konzervatív módon kezeltek mortalitása szignifikánsan nagyobb volt, mint az átlagnépességé. ${ }^{2}$ A Svéd Nemzeti Diabetes Regiszter adatai alapján 1998 és 2014 között az össz-halálozás 29\%-kal csökkent T1DM-ben és 23\%-kal a nem diabeteses, kontrollként szolgáló illesztett (életkor, nem és lakóhely szerint) háttér-populációban. Az össz-mortalitás csökkenésében a két csoport között nem volt különbség. Ugyanebben a periódusban a kardiovaszkuláris betegség (cardiovascular disease, CVD) okozta halálozás 42\%-kal csökkent T1DM-ben és 38\%-kal a kontrollcsoportban; a CVD halálozás csökkenésében szintén nem volt különbség a két csoport között. Ugyanakkor a nem halálos kardiovaszkuláris $(\mathrm{CV})$ kimeneteli mutatók (kórházi felvétel
CVD, akut myocardialis infarctus, koszorúér-betegség [coronary heart disease, $\mathrm{CHD}$ ] vagy stroke miatt) szignifikánsan nagyobb mértékben csökkentek T1DM-ben, mint a kontrollcsoportban. Fontos megfigyelés lehet, hogy a szívelégtelenség miatti hospitalizáció nem mutatott szignifikáns csökkenést egyik csoportban sem. ${ }^{3}$ (A fenti svéd regiszter alapján egyébként a 2-es típusú cukorbetegség is hasonló módon elemzésre került, de ez nem tárgya a jelen összefoglalónak.)

A kedvezően alakuló mortalitási és morbiditási adatok ellenére a halálozás T1DM-ben még mindig 2-8-szoros az átlagnépességhez képest: ez 20 éves életkorban körülbelül 12 évvel csökkenti a várható élettartamot. ${ }^{3,4}$ Új megfigyelés, hogy minél hamarabb kezdődik a T1DM, annál nagyobb a halálozási kockázat, függetlenül a betegségtartamtól: ha a betegség 0-10 éves életkor között indul, akkor az össz-halálozás 4,11-szeresére emelkedik (CVD mortalitás kockázata [HR]: 7,38) a kontrollpopulációhoz képest, míg az emelkedés kisebb, 2,83-szoros (CVD mortalitás HR: 3,64) akkor, ha a T1DM-et 26-30 éves életkor között diagnosztizálják. Az adatok alapján a 10 éves életkor előtt induló T1DM 17,7 évvel csökkenti a várható élettartamot lányok esetében és 14,4 évvel a fiúknál. Mindezek alapján a szerzők felhívják a figyelmet, arra, hogy a kardiovaszkuláris kockázat csökkentése kiemelten fontos korai életkorban kezdődő T1DM esetén. ${ }^{5}$

\section{Kardiovaszkuláris kockázati tényezők 1-es típusú diabetes mellitusban}

A kardiovaszkuláris kockázati tényezők jól ismertek cukorbetegségben, az adatok döntő többsége azonban a 2-es típusú diabetes mellitusra vonatkozik. Jóval kevesebbet tudunk a CV kockázatról és ennek csökkentéséről 1-es típusú cukorbetegségben. Összességében a CV események gyakrabban és fiatalabb életkorban jelennek meg T1DM-ben, mint a nem diabeteses populációban, nőknél különösen nagyobb a kockázat. Az események előfordulása jelentős különbségeket mutat az egyes vizsgálatokban a diabetestartam, a vizsgált 
populáció életkora, neme és etnikai hovatartozása alapján. Egy néhány éve megjelentetett, az AHA (American Heart Association) és az ADA (American Diabetes Association) által összeállított közös nyilatkozat szerint az alábbi relatív kockázati aránnyal (HR) számolhatunk T1DM esetén a háttér-populációhoz (átlagnépesség) képest: ${ }^{6}$

- CVD (kardiovaszkuláris betegség: myocardialis infarctus, koszorúér-revascularisatio, stroke, akut CHD halál) HR: 3,6 (férfi), 7,6 (nő);

- CHD (koszorúér-betegség: myocardialis infarctus, koszorúér-revascularisatio, akut CHD halál) HR: 3,0 (férfi), 7,6 (nő);

- CVA (cerebrovascularis betegség: halálos és nem halálos stroke) HR: 5,9 (nő);

- PAD (perifériás verőér/artériás betegség: nem traumás alsó végtagi amputáció) HR: 85,5. E svéd adat szerint T1DM esetén, 65 éves életkor felett minden 10 nőbeteg közül egy és minden 5 férfi beteg közül egy alsó végtagi nem traumás amputációt szenved el. ${ }^{7}$

Ha a CV kockázati tényezőket összehasonlítjuk a T1DM és T2DM esetén, akkor a hasonlóságok mellett néhány különbséget is észrevehetünk (1. táblázat).

Úgy tűnik, hogy a magas vérnyomás nagyobb szerepet játszik CV rizikótényezőként T1DMben, mint T2DM-ben. A hypertonia gyakrabban fordul elő T1DM-ben - fiatalokat is érintve, függetlenül a diabeteses nephropathia jelenlététől -, mint az átlagnépességben. A DCCT/EDIC vizsgálatban a rossz glykaemiás anyagcsere erôs öszszefüggést mutatott a magas vérnyomással, az intenzív inzulinterápia hosszú távon csökkentette a hypertonia kockázatát. ${ }^{8}$

A gyulladásos markerek növekedése már korán észlelhető a T1DM diagnózisát követően fiataloknál is. A gyulladás kialakulásában és fenntartásában a hyper- és hypoglykaemia, a hízás, a következményes adipokintermelés és a fokozott trombózishajlam egyaránt szerepet játszhat.

T1DM-ben - ha megfelelő a glykaemiás kontroll - általában nincs különbség a lipidekben a nem diabeteses populációhoz képest. Bár a legtöbb, a lipidekre vonatkozó, T1DM-re is kiterjesztett ajánlás 2-es típusú cukorbetegek körében végzett tanulmányokból származik, epidemiológiai vizsgálat T1DM-ben is bizonyította, hogy a $2,6 \mathrm{mmol} / \mathrm{l}$ feletti LDL-koleszterin-szint CV rizikófaktor. ${ }^{9}$
1. táblázat. A kardiovaszkuláris kockázati tényezők és a kardiovaszkuláris események közötti relatív összefüggés 1-es és 2-es típusú cukorbetegségben ${ }^{6}$

\begin{tabular}{|c|c|c|}
\hline & T1DM & T2DM \\
\hline Hypertonia & +++ & ++ \\
\hline Dohányzás & ++ & ++ \\
\hline Gyulladás & ++ & ++ \\
\hline Magas LDL-koleszterin & + & +++ \\
\hline Alacsony HDL-koleszterin & $0,+$ & ++ \\
\hline Triglicerid & nincs adat & ++ \\
\hline Mikroalbuminuria & +++ & +++ \\
\hline Inzulinrezisztencia & + & +++ \\
\hline Rossz glykaemiás állapot & +++ & +++ \\
\hline
\end{tabular}

Bizonyított továbbá, hogy az LDL-koleszterin-szint csökkentése mérsékli a CV események előfordulását. ${ }^{10} \mathrm{Az}$ ajánlások már évek óta javasolják a felnőtt 1-es típusú cukorbetegek statinnal történő kezelését, ha egyéb CV rizikótényező is jelen van; ennek ellenére úgy tűnik, hogy elsősorban a fiatal 1-es típusú betegekre nem fordítunk kellő figyelmet. A fent jelzett svéd mortalitási adatok tükrében ez nem megfelelő gyakorlat. Amerikai kardiológiai ajánlások (American College of Cardiology/American Heart Association) szerint intenzív statinterápia javasolt, ha a 10 éves $\mathrm{CV}$ rizikó $\geq 7,5 \%{ }^{11}$ Gyermekkorban induló T1DM 20 éves fennállása esetén, felnőttkorban évenként a koszorúér-betegség 1\%-os kockázatával számolhatunk, ami tehát önmagában, egyéb CV rizikótényező jelenléte nélkül is kimeríti az intenzív statinkezelési ajánlást. ${ }^{12}$

A diabeteses nephropathia olyan, a T1DM-hez társuló szövődmény, amely jelentős CV kockázati tényezőt is jelent. A diabeteses nephropathia okozhat mikro- vagy makroalbuminuriát, GFRcsökkenést vagy ezeket együttesen. Már a mikroalbuminuria jelenléte fokozott CV rizikóval jár. A makroalbuminuria hatványozottan növeli ezt a kockázatot, részben az LDL-koleszterin-szint következményes emelkedése, a HDL-koleszterinszint csökkenése miatt. (Érdekes megfigyelés, hogy a makroalbuminuria jelenléte T2DM-ben kevésbé tesz hozzá a CV kockázat emelkedéséhez.) A csökkent GFR is növeli a CV kockázatot. A GFR csökkenése előzetes mikro- vagy makroalbuminuria nélkül T1DM-ben is bekövetkezhet, de a jelenség gyakorisága és patomechanizmusa nem tisztázott. ${ }^{6}$ 
$\mathrm{Az}$ inzulinrezisztencia jelen lehet T1DMben, de úgy tűnik, hogy jelentősége kisebb, mint T2DM-ben.

\section{Kardiovaszkuláris rizikócsökkentés 1-es típusú diabetes mellitusban}

A szív- és érrendszeri betegség (koszorúér-betegség, agyérbetegség, perifériás verőérbetegség) ma a vezető mortalitási és morbiditási tényező T1DM-ben is. Emiatt a keringési állapot felmérése és a rizikótényezők rendszeres, legalább évenkénti szűrése, valamint a rizikófaktorok célértékre kezelése elengedhetetlen része az 1-es típusú cukorbeteg gondozásának. A szűrni, illetve kezelni szükséges rizikótényezők a következők: vérnyomás, dyslipidaemia, krónikus vesebetegség, albuminuria, dohányzás és ismerni kell a korai, családi koszorúér-betegség jelenlétét. ${ }^{13}$ A fentieken kívül évente legalább egy alkalommal teljes fizikális vizsgálat, beleértve a láb és a neuropathia vizsgálatát, szemészeti ellenőrzés és nyugalmi EKG készítése szükséges.

A megfelelő glykaemiás állapot elérése - ami talán a legnehezebb feladat T1DM-ben - nem tárgya ennek az összefoglalónak. A jó glykaemiás állapot csökkenti a CV kockázatot. Svéd adatok alapján a $\mathrm{HbA}_{1 \mathrm{c}} 1 \%$-os emelkedése a koszorúér-betegség relatív kockázatát 30\%-kal emeli (HR: 1,3). ${ }^{14}$ Mind az ischaemiás, mind a vérzéses stroke kockázata szorosan összefügg a glykaemiás állapottal, és a $\mathrm{HbA}_{1 \mathrm{c}}$ emelkedésével növekszik. ${ }^{15} \mathrm{Az}$ elérni kívánt $\mathrm{HbA}_{1 \mathrm{c}}$-célérték T1DM-ben is individuális, de általánosan elmondható, hogy törekedni kell a $7 \%$ alatti értékre. ${ }^{16}$ Itt hívjuk fel a figyelmet arra, hogy bizonyított a hypoglykaemia és a CV kockázat összefüggése is. ${ }^{17}$ T1DM-ben már nemcsak az elérni kívánt $\mathrm{HbA}_{1 \mathrm{c}}$-érték alapján javasolt felmérni a glykaemiás állapotot, hanem egyéb, rendkívül fontos paraméterek (pl. hypoglykaemia előfordulása vagy az optimális [vér]cukortartományban eltöltött idő [time in range]) ismerete is szükséges. ${ }^{18}$

$\mathrm{Az}$ ismertetett célértékek és ajánlások az alábbi javaslatokat követik: az Amerikai Diabetes Társaság T1DM-re vonatkozó ajánlása, ${ }^{16}$ az AHA és az ADA 2014-es, közös állásfoglalása az 1-es típusú diabetes és a kardiovaszkuláris betegség tekintetében, ${ }^{11}$ az ADA 2018-as állásfoglalása, ${ }^{13}$ a legújabb európai hypertonia-ajánlás (European Society of Cardiology [ESC] és Europian Society of Hypertension [EHS], 2018) ${ }^{19}$ és a VI. Magyar Kardiovaszkuláris Konszenzus Konferencia (2015) ajánlása. ${ }^{20}$

\section{Vérnyomás}

Egy felmérés szerint a T1DM-es betegek 43\%ának van hypertoniája, ez szám a nem cukorbeteg népességben $15 \%$. T1DM-ben (is) a hypertonia definíciója - megfelelő rendelői körülmények között, ismételten, más napon is mérve - $\geq 140 / 90$ Hgmm-es vérnyomás. A vérnyomást cukorbetegségben minden orvosi megjelenés során mérni kell. A vérnyomást álló helyzetben is meg kell mérni a kezdő vizit alkalmával, és szükség szerint ezt követően is. A hypertonia diagnózisa ambuláns vérnyomásmonitorozás (ABPM), illetve otthoni vérnyomásmérés során észlelt vérnyomás-emelkedés kapcsán szintén felállítható. Az ABPM alapján a hypertonia diagnózisának határértékei a következők: nappali átlag szisztolés érték $(\mathrm{SBP}) \geq 135$ Hgmm és/vagy diasztolés érték (DBP) $\geq 85$ Hgmm, éjjel (alvás közben) SBP $\geq 120 \mathrm{Hgmm}$ és/vagy $\mathrm{DBP} \geq 70 \mathrm{Hgmm}$, 24 órás átlag SBP $\geq 130 \mathrm{Hgmm}$ és/vagy DBP $\geq 80 \mathrm{Hgmm}$; otthoni átlag SBP $\geq 135$ Hgmm és/vagy DBP $\geq 85 \mathrm{Hgmm}^{19}$

Minden magasvérnyomás-betegségben szenvedő cukorbetegnek javasolt a vérnyomás rendszeres otthoni ellenőrzése is. ${ }^{19}$

Ha az orvosi ellenőrzések kapcsán T1DM-ben a vérnyomás 120/80 Hgmm fölé emelkedik, akkor életmódi kezelés (Na-bevitel csökkentése, K-bevitel emelése, több zöldség és gyümölcs fogyasztása, szükség esetén fogyás, kevesebb alkohol, több mozgás) javasolt. A vérnyomás gyógyszeres kezelését T1DM-ben a hypertonia diagnózisának felállításakor (rendelői vérnyomás $\geq 140 / 90 \mathrm{Hgmm}$, egyéb lásd fent) el kell kezdeni! Az első választandó gyógyszercsoport az ACE-gátló, mellékhatás esetén az ARB. A minimális cél a vérnyomás 140/90 Hgmm alá történő csökkentése. Az ADA 2018-as ajánlása szerint fiataloknál vagy fokozott kardiovaszkuláris kockázat esetén még szorosabb célérték elérése jótékony hatású lehet, cél: $<130 / 80 \mathrm{Hgmm}$ vagy <120/80 Hgmm. ${ }^{13}$ Ugyanakkor a 2018-as ESC/EHS ajánlás nem javasolja - cukorbetegségben sem - a szisztolés vérnyomás 
120 Hgmm alá történő csökkentését. Életkor alapján, cukorbetegségben az alábbi célértékeket határozza meg (minden esetben hozzátéve, ha a vérnyomás tolerálható): 18 és 65 éves életkor között SBP <130 Hgmm (de ne <120 Hgmm); 65-79 éves életkor között SBP 130-139 Hgmm, $\geq 80$ év SBP 130-139 Hgmm, a rendelőben mért DBP célértéke 70-79 Hgmm. Időskorban a jelzett célértékek egyéni mérlegelést igényelnek. ${ }^{19}$

\section{Lipidek}

A lipidcsökkentő kezelés T1DM-ben is elsősorban az LDL-koleszterin megfelelő, célértékre törekvő csökkentéséről szól. A gyógyszeres kezelésben a statinok az első választandó készítmények. A kezelés indikációja és intenzitása, valamint az LDLkoleszterin célértéke az alábbi tényezőktől függ: volt-e a betegnek CV eseménye (szekunder prevenció), ha nem volt (primer prevenció), hány éves a beteg, hány éve 1-es típusú cukorbeteg és milyen a $\mathrm{CV}$ rizikóstátusza (vérnyomás, krónikus vesebetegség, albuminuria, dohányzás és a korai, családi kardiovaszkuláris betegség).

Ha volt már CV esemény, akkor - függetlenül az életkortól és az egyéb rizikófaktorok jelenlététől -, intenzív statinkezelés szükséges, a célérték: LDL-koleszterin $\leq 1,8 \mathrm{mmol} / \mathrm{l}$.

Ha nem volt CV esemény és az illető elérte a 40 éves életkort ( $\geq 40$ év), de 75 év alatti, azaz életkora 40 és 75 év közötti, akkor figyelembe véve a betegségtartamot és az egyéb CV rizikótényezőket, közepesen intenzív vagy intenzív statinkezelés javasolt, az LDL-koleszterin célértéke: <2,6 mmol/1 (VI. Magyar Kardiovaszkuláris Konszenzus Konferencia Ajánlása, LDL-koleszterin $<2,5 \mathrm{mmol} / \mathrm{l}^{20}$ ).

Ha nem volt CV esemény és a T1DM-es beteg kevesebb mint 20 éves betegségtartammal 40 év alatti vagy elmúlt 75 éves, akkor egyéni mérlegelés alapján, az egyéb CV kockázati tényezőktől függően a statinkezelés elkezdése javasolt LDL-koleszterin 3,36-4,1 mmol/l közötti értéknél, a célérték: LDLkoleszterin $\leq 2,6 \mathrm{mmol} / 1$ (magyar ajánlás $<2,5$ $\mathrm{mmol} / \mathrm{l}){ }^{15}$ Itt jegyezzük meg, hogy az ADA már gyermekkorban, 10 éves életkor felett is statinkezelést javasol, ha az életmódi terápia ellenére az LDL-koleszterin $>4,1 \mathrm{mmol} / \mathrm{l}$ vagy ha $>3,4 \mathrm{mmol} / \mathrm{l}$ és egyéb $\mathrm{CV}$ rizikó is jelen van. Ebben az esetben is a célérték: LDL-koleszterin $\leq 2,6 \mathrm{mmol} / \mathrm{l}^{21}$
Ha nem volt CV esemény, az illető 40 év alatti, de 1-es típusú cukorbetegsége gyermekkorában kezdődött és a betegségtartam eléri a 20 évet, akkor - egyéb rizikótényezők nélkül is - az intenzív statinkezelés megfontolandó, hiszen a 10 évre vetített CV kockázat $\geq 7,5 \%$, az LDL-koleszterin célértéke <2,6 mmol/l (magyar ajánlás <2,5 mmol/l). ${ }^{13,15}$ Mint korábban utaltunk rá, az amerikai kardiológiai társaságok kockázatbecslése intenzív statinterápiát javasol azoknak, akiknek a 10 éves CV kockázata a eléri vagy meghaladja 7,5\%-ot. Gyermekkori indulású T1DM esetén, 20 éves betegségtartamot követően a kockázat ebben a tartományban van, tehát az intenzív statinkezelés megfontolandó.

$\mathrm{Az}$ intenzív statinterápia napi $40-80 \mathrm{mg}$ atorvastatin vagy $20-40 \mathrm{mg}$ rosuvastatin adását jelenti, amelynek hatására az LDL-koleszterin kiindulási szintjének legalább 50\%-os csökkenése várható. A közepesen intenzív statinkezelés az alábbi gyógyszereket és napi dózisokat jelenti: atorvastatin 10-20 mg, rosuvastatin 5-10 mg, simvastatin $20-40 \mathrm{mg}$, fluvastatin XL $80 \mathrm{mg}$; az LDLkoleszterin várható csökkenése 30-50\% közötti. ${ }^{13}$

Ha CV esemény után vagy ismert kardiovaszkuláris betegség mellett önmagában statinkezeléssel nem érjük el a kívánt célértéket, akkor a terápia ezetimibbel vagy szubtilizin/kexin proprotein-konvertáz enzim 9-gátló (PCSK9) inhibitorral történő kiegészítése szükséges. ${ }^{13}$

Várandósság idején a statinkezelés ellenjavallt. ${ }^{13}$

\section{Thrombocytaaggregáció-gátló kezelés}

Szekunder prevencióra az aszpirinterápia kötelező (napi 75-162 mg, hazánkban az átlagos dózis napi $100 \mathrm{mg}$ ). Dokumentált aszpirin-allergia esetén napi $75 \mathrm{mg}$ clopidogrel adása szükséges. Kettős thrombocytaaggregáció-gátló kezelés javasolt akut coronaria szindróma után egy évig, de ezt követően is felmerülhet e terápia alkalmazása és lehetséges előnye. ${ }^{13}$

T1DM-ben primer prevencióként az aszpirinterápia megfontolandó, 50 év feletti nők és férfiak esetén, ha a T1DM-en kívül legalább egy $\mathrm{CV}$ rizikófaktor jelen van (korai családi atheroscleroticus eredetű kardiovaszkuláris betegség, magas vérnyomás, dyslipidaemia, krónikus vesebetegség, albuminuria, dohányzás) és a betegnek 
nincs fokozott vérzési kockázata. ${ }^{13}$ Ugyanakkor a legújabb tanulmány, amely az aszpirinkezelés hatékonyságát vizsgálta primer prevencióként cukorbetegségben, a vártnál szerényebb eredményt hozott. Az ASCEND (A Study of Cardiovascular Events in Diabetes) kettős vak, randomizált, kontrollált vizsgálat volt, amelybe 40 év feletti (átlagéletkor 63 év) cukorbetegeket vontak be (94\%-uk T2DM) az aktív ágon $(\mathrm{n}=7740) 100 \mathrm{mg}$ aszpirint, az összehasonlító ágon $(\mathrm{n}=7740)$ placebót kaptak a betegek, a követés tartama 7,4 év volt. Az aszpirint kapók csoportjában a $\mathrm{CV}$ események relatív kockázata $12 \%$-kal csökkent (vs. placebó), a nagy vérzéses eseményeké pedig 29\%-kal nőtt. ${ }^{22}$

\section{Albuminuria és vesefunkció vizsgálata}

A mikroalbuminuria (vizelet-albuminürítés 30-299 $\mathrm{mg} / 24$ óra) vagy a makroalbuminuria (albuminürítés $\geq 300 \mathrm{mg} / 24$ óra), valamint az eGFR csökkenése egyaránt emeli a CV kockázatot. A mikroalbuminuria megjelenése T1DM-ben a nephropathia még reverzíbilis szakaszára utalhat. A fentiek miatt legalább évente egy alkalommal a mikroalbuminuria és az egyéb vesefunkciós paraméterek (vizeletvizsgálat, karbamid-nitrogén, eGFR) vizsgálata javasolt, szükség esetén a vizsgálatok megismétlésével. Saját gyakorlatunk a mikroalbuminuria szűrésére egyszeri (reggeli első) vizeletmintát alkalmazunk. Ennek pozitivitása esetén gyüjtött vizeletben mérjük az albuminürítést. A mikroalbuminuria diagnózisakor (3 vizeletgyüjtésből 2 a mikroalbuminuria tartományába esik) ACE-gátló (mellékhatás esetén ARB) kezelés indítása szükséges.

Ma már tudjuk, hogy cukorbetegségben normális albuminürítés mellett is romolhat a vesefunkció.

\section{Túlsúly}

Bár régebben a T1DM típusosan a soványak betegsége volt, ez ma megváltozott. Míg a DCCT vizsgálatban a vizsgálat kezdetén a betegek csupán $1 \%$-a volt elhízott (BMI $\left.\geq 30 \mathrm{~kg} / \mathrm{m}^{2}\right)$, addig a vizsgálatot követő EDIC tanulmány 12. évében ez az arány már $31 \%$ volt! ${ }^{23}$ Egy másik tanulmány azt mutatta, hogy a halálozás szempontjából az optimális BMI T1DM-ben nagyobb, mint a nem diabeteses populációban, nevezetesen $25-30 \mathrm{~kg} / \mathrm{m}^{2}$ közötti BMI mellett volt a legkisebb mortalitás. ${ }^{24}$
Mindenképpen kerülni kell a hasra lokalizálódó elhízást. Hazai vizsgálat is bizonyította, hogy hosszú betegségtartamú T1DM esetén megjelenhetnek a T2DM-re jellemző fenotípus-tulajdonságok. ${ }^{25} \mathrm{Az}$ elhízás megelőzéséhez a legjobb módszer az egészséges életmód, amely megfelelő táplálkozást és rendszeres fizikai aktivitást jelent. A hypoglykaemia-kockázat csökkentése segíthet a testsúlynövekedés elkerülésében. A rendszeres mozgás kardioprotektív hatása pedig messze felülírja a mozgásnak a cukoranyagcserére gyakorolt esetleges labilitást fokozó hatását. Utóbbit csökkenthetjük és meg is előzhetjük megfelelő betegedukációval és saját tapasztalat gyüjtésével.

\section{Egyéb kardiovaszkuláris szürővizsgálatok}

Gyakran felmerül, hogy az évi egy alkalommal történő fizikális vizsgálaton és nyugalmi EKG-n túl szükséges-e egyéb $\mathrm{CV}$ vizsgálatokat (echocardiographia, carotis-ultrahang, terheléses EKG stb.) rendszeresen végezni panaszmentes, korábbi CV esemény nélküli, T1DM-es betegek körében. Az ADA 2018-as ajánlása szerint, ha a beteg panaszmentes, valamint a primer prevenciós kezelést a fenti stratégia szerint folytatjuk, akkor nem javasolt további kardiológiai vizsgálat. ${ }^{13}$ Bármilyen panasz vagy atherosclerosisra utaló tünet esetén azonban a kivizsgálást el kell kezdeni!

Ugyanakkor fontos megjegyeznünk, hogy a cukorbetegséghez társuló neuropathia elfedheti az atherosclerosis okozta tüneteket, pl. az anginát. A kardiológiai szakirodalom - nemzetközi szinten - azt hangsúlyozza, hogy a kis és közepes kockázatú betegek esetében a kalciumscore vizsgálat vagy a kontrasztanyag adását igénylő coronaria-CT az elsőként elvégzendő vizsgálat. ${ }^{26}$ Nem vitatható, hogy hazánkban ezek a módszerek még nehezen érhetőek el, de remélhetőleg a szakma ajánlásának megfelelően a lehetőségek nálunk is bővülnek majd.

Ami ma is megvalósítható (lenne) hazánkban, az egyik leghatékonyabb kardiovaszkuláris prevenció: a cukorbeteg nem dohányozhat!

\section{Szemészet, neuropathia}

A klasszikusan microangiopathiás szövődményként véleményezett retino- és neuropathia ismerete igen fontos a kardiovaszkuláris állapot 
felmérésében. Gondoljunk csak arra, hogy a szemfenéki erek tükrözik a szervezet érstátuszát, a diabeteses autonóm neuropathia jelenléte pedig többszörösen emeli a CV halálozást.

Szűrővizsgálatként - panaszmentesség esetén is - évente egy alkalommal szemészeti vizsgálat (visus, nyomás, tágított pupillánál szemfenék), a szenzoros neuropathia vizsgálata (láb megtekintése, hangvilla, monofilamentum) és az autonóm neuropathia felmérése (légzési aritmia megléte/hiánya, nyugalmi szívfrekvencia mérése, valamint az ortosztatikus vérnyomásesés vizsgálata) javasolt.

\section{Összefoglalás}

1-es típusú cukorbetegeink gondozása során is jelentős figyelmet kell fordítani a szív- és érrendszeri betegségek megelőzésére. Ennek része a megfelelő glykaemiás kontroll mellett az egyéb kardiovaszkuláris rizikótényezők rendszeres felmérése és a célértékre történő, akár gyógyszeres kezelés. Az utóbbi időben megjelent mortalitási/morbiditási eredmények azt mutatják, hogy a gyermekkorban kezdődő és hosszú betegségtartamot jelentő T1DM már fiatal felnőttkorban jelentősen rontja az életkilátást, ezért a korai kardiovaszkuláris prevenció fontos aspektusa a fiatal 1-es típusú cukorbetegek gondozásának.
Irodalom

1. Morimoto A, Onda Y, Nishimura R, Sano H, Utsunomiya K, Tajima N; Diabetes Epidemiology Research International Mortality Study Group: Cause-specific mortality trends in a nationwide population-based cohort of childhood-onset type 1 diabetes in Japan during 35 years of follow-up: the DERI Mortality Study. Diabetologia 2013; 56: 2171-2175. doi:10.1007/s00125-013-3001-2

2. Diabetes Control and Complications Trial (DCCT)/Epidemiology of Diabetes Interventions and Complications (EDIC) Study Research Group: Mortality in type 1 diabetes in the DCCT/EDIC vs. the general population. Diabetes Care 2016; 39: 1378-1383. doi:102337/dc15-2399

3. Rawshani A, Rawshani A, Franzén S, Eliasson B, Svenson AM, Miftaraj M, et al:: Mortality and cardiovascular disease in type 1 and type 2 diabetes. N Eng J Med 2017; 376(15): 1407-1408. doi:10.1056/NEJMoa1608664

4. Livingstone S, Levin D, Looker HC, Lindsay RS, Wild SH, Joss $\mathrm{N}$, et al: Estimated life expectancy in a Scottish cohort with type 1 diabetes, 2008-2010. JAMA 2015; 313:37-44. doi:10.1001/jama.2014.16425

5. Rawshani A, Sattar N, Franzén S, Rawshani A, Hattersley AT, Svenson AM, et al.: Excess mortality and cardiovascular disease in young adults with type 1 diabetes in relation to age at onset: a nationwide, register-based cohort study. Lancet 2018; 392: 477-486. doi:10.1016/50140-6736(18)31506-X

6. de Ferranti SD, de Boer IH, Fonseca V, Fox CS, Hill Golden S, Lavie CJ, et al: Type 1 diabetes mellitus and cardiovascular disease: a scientific statement from the American Heart Association and American Diabetes Association. Diabetes Care 2014; 37: 2843-2863. doi:10.2337/dc14-1720

7. Jonasson JM, Ye W, Sparén P, Apelqvist J, Nyrén O, Brismar K: Risks of nontraumatic lower-extremity amputations in patients with type 1 diabetes: A population-based cohort study in Sweden. Diabetes Care 2008; 31: 1536-1540. doi:10.2337/dc08-0344

8. de Boer IH, Kestenbaum B, Rue TC, Steffes MW, Cleary PA, Molitch ME, et al.: Diabetes Control and Complications Trial (DCCT)/Epidemiology of Diabetes Interventions and Complications (EDIC) Study Research Group.: Insulin therapy, hyperglycemia, and hypertension in type 1 diabetes mellitus. Arch Intern Med 2008; 168: 1867-1873. do: 10.1001/archinternmed.2008.2

9. Orchard TJ, Forrest KY, Kuller LH, Becker DJ; Pittsburgh Epidemiology of Diabetes Complications Study: Lipid and blood pressure treatment goals for type 1 diabetes: 10-year incidence data from the Pittsburgh Epidemiology of Diabetes Complications Study. Diabetes Care 2001; 24: 1053-1059. doi:10.2337/diacare.24.6.1053

10. Cholesterol Treatment Trialists' (CTT) Collaboration, Baigent C, Blackwell L, Emberson J, Holland LE, Reith C, Bhala N, et al.: Efficacy and safety of more intensive lowering of LDL cholesterol: a meta-analysis of data from 170,000 participants in 26 randomised trials. Lancet 2010; 376(9753): 1670-1681. doi:10.1016/50140-6736(10)61350-5

11. Stone NJ, Robinson JG, Lichtenstein AH, Bairey Merz CN, Blum CB, Eckel RH, et al: American College of Cardiology/American Heart Association Task Force on Practice Guidelines 2013 ACC/AHA guideline on the treatment of blood cholesterol to reduce atherosclerotic cardiovascular risk in adults: a report of the American College of Cardiology/American Heart Association Task Force on Practice Guidelines. J Am Coll Cardiol 2014; 63(25 Pt B): 2889-2934. doi:10.1016/j.jacc.2013.11.002

12. Orchard TJ, Costacou T, Kretowski A, Nesto RW: Type 1 diabetes and coronary artery disease. Diabetes Care 2006; 29(11): 2528-2538. doi:10.2337/dc06-1161

13. American Diabetes Association: 9. Cardiovascular disease and risk management: Standard of medical care in diabetes-2018. Diabetes Care 2018; Suppl. 1: S86-104. doi:10.2337/dc18-S009 
14. Eeg-Olofsson K, Cederholm J, Nilsson PM, Zethelius B, Svensson AM, Gudbjörnsdóttir S, et al.: Glycemic control and cardiovascular disease in 7,454 patients with type 1 diabetes: an observational study from the Swedish National Diabetes Register (NDR). Diabetes Care 2010; 33: 1640-1646. doi: $10.2337 / \mathrm{dc} 10-0398$

15. Ståhl CH, Lind M, Svensson AM, Gudbjörnsdottir S, Mårtensson A, Rosengren A: Glycaemic control and excess risk of ischaemic and haemorrhagic stroke in patients with type 1 diabetes: a cohort study of 33453 patients. J Intern Med 2017; 281: 261-272. doi:10.1111/joim. 12572

16. Chiang JL, Kirkman MS, Laffel LM, Peters AL, on behalf of the Type 1 Diabetes Sourcebook Authors: Type 1 diabetes through the life span: a position statement of the American Diabetes Association. Diabetes Care 2014; 37: 2034-2054. doi: $10.2337 / \mathrm{dc} 14-1140$

17. Giménez M, Gilabert R, Monteagudo J, Alonso A, Casamitjana R, Paré C, et al.: Repeated episodes of hypoglycemia as a potential aggravating factor for preclinical atherosclerosis in subjects with type 1 diabetes. Diabetes Care 2011; 34(1): 198-203. doi:10.2337/dc10-1371

18. Agiostratidou G, Anhalt H, Ball D, Blonde L, Gourgari ER, Harriman KR, et al: Standardizing clinically meaningful outcome measures beyond $\mathrm{HbA}_{1 \mathrm{c}}$ for type 1 Diabetes: a consensus report of the American Association of Clinical Endocrinologist, the American Association of Diabetes Educators, the American Diabetes Association, the Endocrine Society, JDRF International, the Leona M and Harry B. Helmsley Charitable Trust, the Pediatric Endocrine Society, and the T1D Exchange. Diabetes Care 2017; 40: 1622-1630. doi:10.2337/dc17-1624

19. Williams B, Mancia G, Spiering W, Agabiti Rosei E, Azizi M, Burnier M, et al: 2018 ESC/ESH Guideline for the management of arterial hypertension. Eur Heart J 2018; 39(33): 3021-3104. doi:10.1093/eurheartj/ehy339

20. Pados Gy, Bedros JR, Simonyi G, Paragh Gy, Jermendy Gy, Karádi I, et al. Összefoglalás a VI. Magyar Kardiovaszkuláris Konszenzus Konferencia irányelveiról. Metabolizmus 2015; 13(1): 1-3.

21. American Diabetes Association: 12. Children and Adolescents: Standards of medical care in diabetes - 2018. Diabetes Care 2018; 41(Suppl. 1): S126-S136. doi:10.2337/dc18-S012
22. ASCEND Study Collaborative Group: Effects of aspirin for primary prevention in persons with diabetes mellitus. N Engl I Med 2018; 379: 1529-1539. doi:10.1056/NEJMoa1804988

23. Purnell JQ, Dev RK, Steffes MW, Cleary PA, Palmer JP, Hirsch IB, et al: Relationship of family history of type 2 diabetes, hypoglycemia, and autoantibodies to weight gain and lipids with intensive and conventional therapy in the Diabetes Control and Complications Trial. Diabetes 2003; 52: 2623-2629. doi:10.2337/diabetes.52.10.2623

24. Conway B, Miller RG, Costacou T, Fried L, Kelsey S, Evans RW, et al: Adiposity and mortality in type 1 diabetes. Int J Obes (Lond) 2009; 33: 796-805. doi:10.1038/ijo.2009.75

25. Nádas J, Putz Z, Fövényi J, Gaál Z, Gyimesi A, Hidvégi T, et al.: Cardiovascular risk factors characteristic for the metabolic syndrome in adult patients with type 1 diabetes. Exp Clin Endocrinol Diabetes 2009; 117: 107-112. doi:10.1055/s-0028-1082068

26. Maurovich-Horvat $P$, Móri T, Kerecsen G, Fövényi J, Sallai T, Soós $P$, et al: Assessment of coronary artery calcification using dual-source computed tomography in adult asymptomatic patients with type 1 diabetes mellitus. MedSciMonit 2010; 16: MT59-64. PMID: 20581785

Közlésre érkezett: 2018. december 28.

Közlésre elfogadva: 2019. május 16.

\section{A levelezésért felelös szerzö címe:}

\section{Dr. Kempler Miklós}

Semmelweis Egyetem, III. Belgyógyászati Klinika 1125 Budapest, Kútvölgyi út 4.

E-mail: kemplersoma@gmail.com 